\title{
Stigma: A Social, Cultural, and Moral Process
}

\section{Citation}

Kleinman, Arthur and Rachel Hall-Clifford. Forthcoming. Stigma: A social, cultural, and moral process. Journal of Epidemiology and Community Health 63(6).

\section{Published Version}

http://jech.bmj.com/

\section{Permanent link}

http://nrs.harvard.edu/urn-3:HUL.InstRepos:2757548

\section{Terms of Use}

This article was downloaded from Harvard University's DASH repository, and is made available under the terms and conditions applicable to Open Access Policy Articles, as set forth at http:// nrs.harvard.edu/urn-3:HUL.InstRepos:dash.current.terms-of-use\#OAP

\section{Share Your Story}

The Harvard community has made this article openly available.

Please share how this access benefits you. Submit a story.

\section{Accessibility}




\section{Journal of Epidemiology and Community Health \\ Editorial \\ Arthur Kleinman, Rachel Hall-Clifford}

\section{Stigma: A social, cultural, and moral process}

The concept of stigma has undergone important shifts in definition and characterization since its initial articulation by Erving Goffman in the 1960s. Here, we contend that the study of stigma has focused too heavily on psychological approaches and has neglected to sufficiently incorporate understandings of stigma and stigmatized individuals as embedded in local moral contexts. What exactly is encompassed by the conceptual umbrella of stigma is far more than a compelling theoretical question, since definitions of stigma directly inform efforts to empirically research and combat stigma.

The modern idea of stigma owes a great deal to Goffman, who viewed stigma as a process based on the social construction of identity. Persons who become associated with a stigmatized condition thus pass from a "normal" to a "discredited" or "discreditable" social status. ${ }^{1}$ In his original discussion of stigma, Goffman included both psychological and social elements, but his ideas have primarily been used in the analysis of psychological impact of stigma on individuals. This has created an understanding of the psychology of the stigmatized,

focusing on the processes by which stigma is internalized and shapes individual behavior. Yet, 
this has been to the exclusion of considerations of how social life and relationships are changed by stigma. ${ }^{2}$

Recently, the field of sociology has contributed to this discussion by creating a broader understanding of stigma that identifies social processes that occur within the sociocultural environment whose effects can be observed within the individual. Specifically, the model of stigma proposed by Link and Phelan ${ }^{3}$ includes a component of structural discrimination, or the institutionalized disadvantages placed on stigmatized groups. This opens the door for us to begin to elucidate the ways that power - social, economic, and political - shapes the distribution of stigma within a social milieu.

More recently, anthropological contributions to the study of stigma have focused on stigma as embedded in moral experience and on the stigmatized as a person with a moral status. $^{4,5}$ The moral standing of an individual or group is determined by their local social world, and maintaining moral status is dependent on meeting social obligations and norms. Individuals with (or associated with) stigmatized conditions are de facto unable to meet these requirements. Thus, stigma decays the ability to hold on to what matters most to ordinary people in a local 
world, such as wealth, relationships, and life chances. Yet, we must remember that the stigmatized and those who stigmatize are interconnected through local social networks. Although stigma may share features across contexts, it uniquely affects lives in local contexts.

Understanding the unique social and cultural processes that create stigma in the lived worlds of the stigmatized should be the first focus of our efforts to combat stigma. Measuring what matters most is facilitated by ethnographic methods, through which the local value systems can be explored in far greater depth than what is possible through standard survey instruments. By combining observation with in-depth interviews, we can see the difference between individual's stated moral ideals and their actions. This knowledge in turn facilitates understanding what stigma does to people and how it can be addressed.

The present focus on legislation to prevent formal, institutionalized consequences of stigma is admirable, but it does not create large social change. Anthropology can contribute to this discussion by examining the altering of moral worlds that lead to large cultural changes. We only have to look to the examples of depression and smoking in the U.S. context to see that the relative stigma of specific conditions and actions can and does change across time. For example, 
there is a significant trend toward destigmatization of depression that indicates a major cultural shift. ${ }^{6}$ Conversely, smoking has become increasingly stigmatized, and smoking rates in the U.S. have substantially dropped. ${ }^{7}$ Despite much scholastic attention and public education efforts to achieve these trends, we do not really understand the processes by which these shifts in norms and moral experience have occurred.

We currently know surprisingly little about the moral processes that undergird stigma. Until we admit this, we will limit our ability to understand and create effective strategies for overcoming stigma. Most stigma research has failed to address this central issue. In addition to the psychological and macrosocial components of stigma, we must understand how the moral standing of individuals and groups in local context affects the transmission and outcome of stigma. By focusing on how local values enacted in people's lives affect stigma, we will be able to create more effective and measureable anti-stigma interventions.

\footnotetext{
${ }^{1}$ Goffman E. Stigma: Notes on the management of spoiled identity. New York: Prentice-Hall, 1963.

${ }^{2}$ Parker P, Appleton P. HIV and AIDS-related stigma and discrimination: a conceptual framework and implications for action. Social Science and Medicine 2003;57:13-24.

${ }^{3}$ Link BG, Phelan JC. Conceptualizing stigma. Annual Review of Sociology 2001;27:363-385.
} 
${ }^{4}$ Yang LH, Kleinman A, Link BG, Phelan JC, Lee S, Good B. Culture and stigma: Adding moral experience to stigma theory. Social Science and Medicine 2007;64:1524-1535.

${ }^{5}$ Yang LH, Kleinman A. 'Face' and the embodiment of stigma in China: The cases of schizophrenia and AIDS. Social Science and Medicine 2008;67:398-408.

${ }^{6}$ Olfson M, Marcus SC, Druss B, Elinson L, Tanielian T, Pincus HA. National Trends in the Outpatient Treatment of Depression. JAMA 2002;287:203-209.

${ }^{7}$ Gilpin EA, Lee L, Pierce JP. Changes in population attitudes about where smoking should not be allowed: California versus the rest of the USA. Tobacco Control 2004;13:38-44. 